Note

\title{
Distribution patterns and dynamics of phosphorus forms in the overlying water and sediment of Dongting Lake
}

\author{
Lingqing Wang *, Tao Liang \\ Key Laboratory of Land Surface Pattern and Simulation, Institute of Geographical Sciences and Natural Resources Research, Chinese Academy of Sciences, Beijing 100101, China
}

\section{A R T I C L E I N F O}

\section{Article history:}

Received 16 November 2015

Accepted 17 March 2016

Available online 16 April 2016

Communicated by Gerald Matisoff

\section{Index words:}

Phosphorus

Sediment

Overlying water

Adsorption

Desorption

\begin{abstract}
A B S T R A C T
Dongting Lake is a typical shallow lake in the lower Yangtze region and is the second largest freshwater lake in China. The distribution, speciation, and sediment release characteristics of phosphorus $(\mathrm{P})$ were investigated by analyzing sediment and water samples collected during high and low flow periods. The average concentration (range) of total phosphorus (TP) in the water was $0.05 \mathrm{mg} \mathrm{L}^{-1}\left(0.02 \sim 0.09 \mathrm{mg} \mathrm{L}^{-1}\right)$, while the value in sediment was $703 \mathrm{mg} \mathrm{kg}^{-1}$ ( $466 \sim 869 \mathrm{mg} \mathrm{kg}^{-1}$ ). The concentrations of TP and different $P$ forms decreased as depth increased. Inorganic phosphorus was the dominant form of P, accounting for $72 \%$ of TP. The bioavailable P was a relatively large portion of TP, indicating a high risk of P release to overlying water. The Langmuir equation can well describe the $\mathrm{P}$ isotherm adsorption characteristics in sediment. The amount of P desorption from sediment tended to increase with increasing concentrations of adsorbed P.
\end{abstract}

(c) 2016 International Association for Great Lakes Research. Published by Elsevier B.V. All rights reserved.

\section{Introduction}

Phosphorus $(\mathrm{P})$ is one of the key factors that influence primary productivity in lake ecosystems, and it is also a crucial control factor that causes abnormal proliferation of both phytoplankton and eutrophication (Matias and Johnes, 2012; Chen et al., 2015). When external P loads are reduced in shallow lakes, internal $P$ release can be a key factor contributing to eutrophication, and thus may interfere with lake restoration efforts (Nürnberg et al., 1986; Loh et al., 2013; Powers et al., 2014). Sediment, a critical source and reservoir of nutrients in lake ecosystems, can play a very important role in the process of eutrophication (Haggard et al., 2012; Kraal et al., 2015). The diffusion of P at the watersediment interface is dependent not only on P absorption-desorption from sediment, but also on a number of physical and chemical parameters (Nürnberg et al., 1986; Ishii et al., 2010; Loh et al., 2013; Wang and Liang, 2014).

Dongting Lake, connected to the Yangtze River, is the second largest freshwater lake in China. The growing pollution, especially from papermaking, textile industries, and agricultural non-point source pollution has degraded the ecological environment of Dongting Lake basin. In this study, water and sediment samples collected from Dongting Lake during different periods of the hydrological cycle were measured for $\mathrm{P}$ concentrations and distribution characteristics. These P characteristics were analyzed in order to characterize the migration of nutrients from

\footnotetext{
* Corresponding author.

E-mail address: wanglq@igsnrr.ac.cn (L. Wang).
}

the water-sediment interface of the lake and to understand the water-environmental effects of the coupled river-lake relation.

\section{Materials and methods}

\section{Site description}

Dongting Lake is located in the northeast of Hunan Province on the south bank of the middle Yangtze River between E110 $40^{\prime}-113^{\circ} 10^{\prime}$ and $\mathrm{N} 28^{\circ} 30^{\prime} \sim 30^{\circ} 20^{\prime}$ (Fig. 1). Due to the historical evolution and extensive sediment deposition, the lake has been divided into three parts (Eastern Dongting Lake, Southern Dongting Lake and Western Dongting Lake). The water area of the lake varies greatly. In the dry season, the lake occupies as little as $2.74 \times 10^{3} \mathrm{~km}^{2}$; but during the flooding season, it expands to $1.2 \times 10^{4} \mathrm{~km}^{2}$. The average depth of the lake is $6.39 \mathrm{~m}$ with a corresponding water storage of 16.7 billion $\mathrm{m}^{3}$. The hydraulic residence time was $18 \mathrm{~d}$ before the building of the Three Gorges Dam and now is greater than $29 \mathrm{~d}$ (Huang et al., 2013).

\section{Sample collection and analysis}

Surface sediment samples were collected at 20 sampling sites located at the entrances of four rivers, in the main lake area, and at the outlets of all the lake areas. Ten sediment samples (labeled D1 D10) were collected from Eastern Dongting Lake, four (labeled D11 D14) from Southern Dongting Lake and six (labeled D16 D20) from Western Dongting Lake. Surface water and deep water samples were collected at each site. Three parallel samples were collected at each site. Six 
sediment cores (labeled C1 C6) were also collected with a gravity sampler at each site in Western Dongting Lake. The top $20 \mathrm{~cm}$ of each core was sectioned into $1-\mathrm{cm}$ increments by pushing out the mud column with a piston and using metal fixed rings and inserts to stratify the cores. The forms of P present were determined using the standard measurement and test (SMT) procedure (Ruban et al., 1999; Ding et al., 2015). The forms consist of iron- and aluminum-bound phosphorus (NaOH-P), calcium-bound phosphorus ( $\mathrm{HCl}-\mathrm{P})$, inorganic phosphorus (IP), organic phosphorus (OP), and total phosphorus (TP).

\section{P adsorption-desorption experiment}

Study of phosphate adsorption isotherms was carried out with different initial phosphate concentrations at room temperature $(22 \pm$ $\left.1{ }^{\circ} \mathrm{C}\right)$. Eight levels of initial P concentrations $(2,4,10,20,30,40,60$, and $80 \mathrm{mg} \mathrm{L}^{-1}$ ) were tested. The samples were shaken (200 rpm) and then centrifuged ( $4000 \mathrm{rpm}$ ) for $10 \mathrm{~min}$. The supernatants were filtered through a $0.45 \mu \mathrm{m}$ filter and analyzed for P concentrations. Sediment residues from adsorption experiments were equilibrated with $25 \mathrm{~mL}$ of $0.01 \mathrm{~mol} \mathrm{~L}^{-1} \mathrm{KCl}$ solution. The samples were then shaken for $24 \mathrm{~h}$, and centrifuged at $4000 \mathrm{rpm}$ for $10 \mathrm{~min}$. The supernatants were filtered through a $0.45 \mu \mathrm{m}$ filter and analyzed for desorbed $\mathrm{P}$, as described in adsorption experiments.

The P concentrations in supernatant samples were measured using Inductively Coupled Plasma-Optical Emission Spectrometry (ICP-OES, OPTIMA 5300DV, Perkin Elmer). The detection limit of ICP-OES is $10 \mu \mathrm{g} \mathrm{L}^{-1}$. Quality control was achieved with certified reference samples, GBW07303 from the National Research Center for Certified Reference Materials (Beijing, China). The results for the reference samples correlated with the reference values, with the deviations less than $5 \%$.

\section{Data analysis}

The experimental adsorption data were fitted to the Langmuir equation (Xu et al., 2014; Wang and Liang, 2014), which is described by: $C / Q=C / Q_{m}+1 /\left(K Q_{m}\right)$. In the equation, $C$ is the $P$ concentration $\left(\mathrm{mg} \mathrm{L}^{-1}\right)$ in the adsorption equilibrium solution; $Q$ is the equilibrium adsorption capacity $\left(\mathrm{mg} \mathrm{kg}^{-1}\right) ; Q_{m}$ is the maximum adsorption $\left(\mathrm{mg} \mathrm{kg}^{-1}\right.$ ) of $\mathrm{P}$ in sediment and $K$ is the Langmuir adsorption constant $\left(\mathrm{L} \mathrm{mg}^{-1}\right)$.

All statistical analyses were conducted using SPSS 13.0 software package (SPSS Inc., Chicago, IL). The spatial variability of TP in sediment and water was analyzed using the geology-statistical analysis module of ArcGIS 10.02 (ESRI, Redlands, CA, USA). Contour diagrams were plotted using Surfer 9.0 (Golden Software Inc., CO, USA). Origin 8.0 was used for creating the figures.

\section{Results and discussion}

The distribution characteristics of TP in sediment and water

The results of a one-way ANOVA showed that the spatial variation of TP concentrations among different Dongting Lake sediment samples was significant $(P<0.05)$. The average concentration of TP in sediment was $703 \mathrm{mg} \mathrm{kg}^{-1}$, ranging from 466 to $869 \mathrm{mg} \mathrm{kg}^{-1}$. The TP concentration showed a decreasing trend from the inlet to the lake areas and from Eastern Dongting Lake to Western Dongting Lake and then South Dongting Lake (Fig. 2a). The TP concentration in the Xiangjiang River was the highest among all of the inlets. The Xiangjiang River had the highest value of TP in Lujiao and Zhangshugang, likely due to the pollution caused by soil and water loss, aquaculture, pesticides and fertilizers, as well as livestock manure in the upper reaches. The average concentration (range) of TP in sediment during the high flow period was

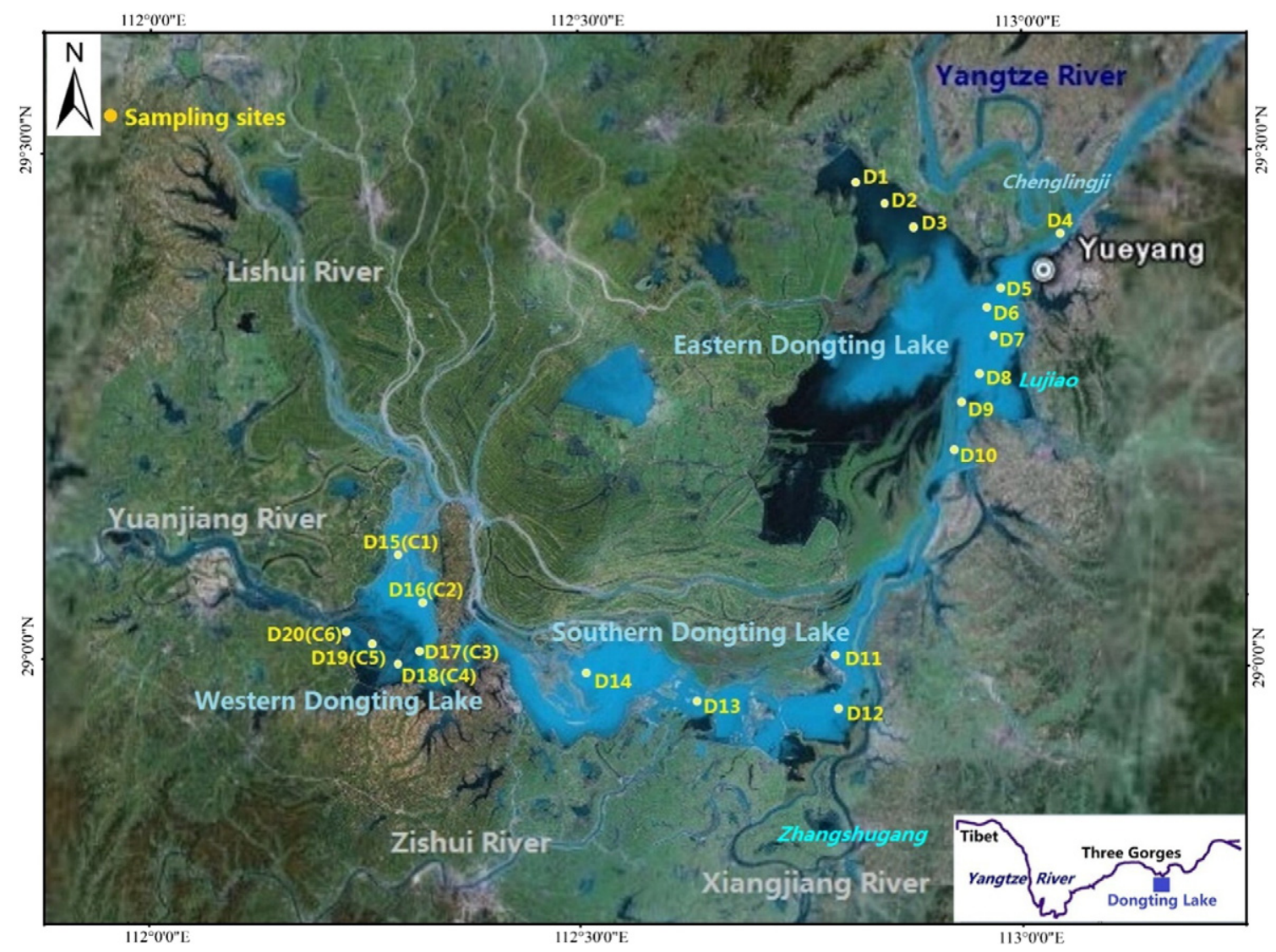

Fig. 1. Location of major inflowing rivers, sampling sites in Dongting Lake and its relation to the Yangtze River (upper right). 

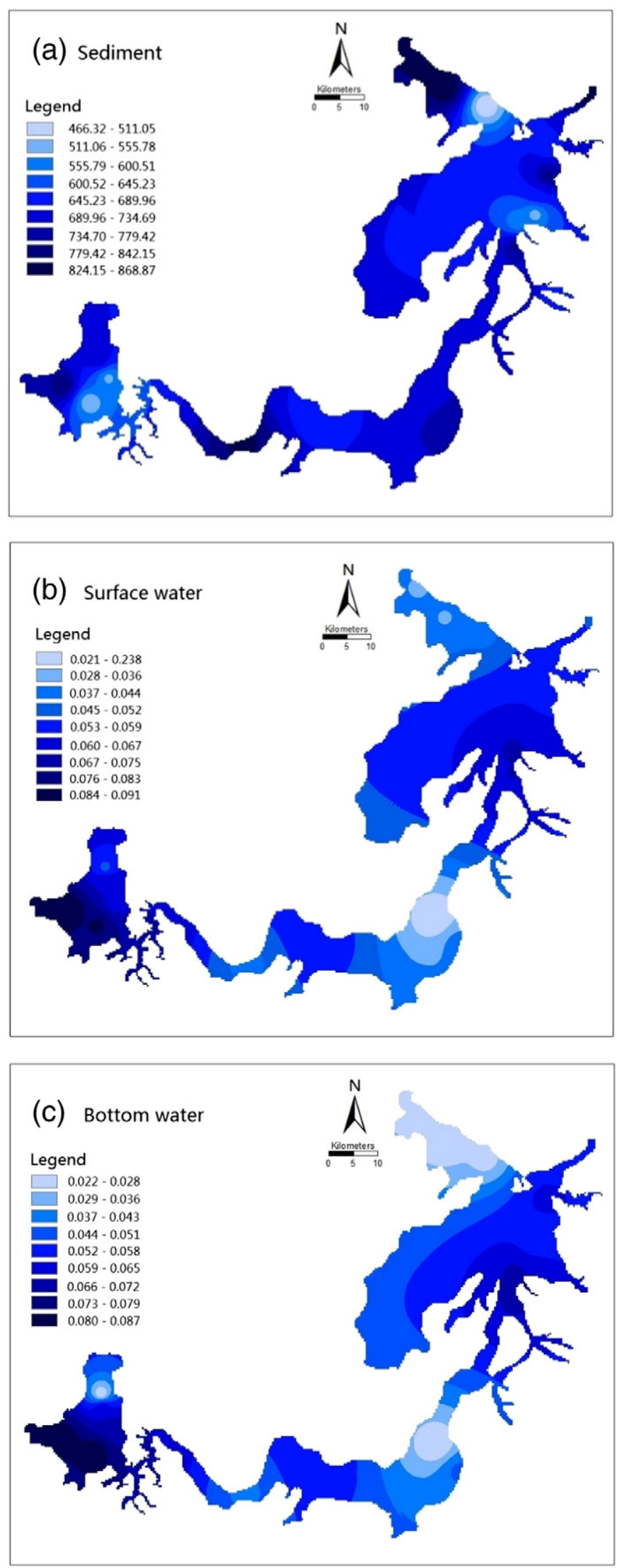

Fig. 2. Spatial distributions of TP in the sediment (panel a) as $\mathrm{mg} \mathrm{kg}^{-1}$ and surface (panel b) and bottom (panel c) water as $\mathrm{mg} \mathrm{L}^{-1}$ in Dongting Lake.
$819.05 \mathrm{mg} \mathrm{kg}^{-1}$ (516 $\left.1174 \mathrm{mg} \mathrm{kg}^{-1}\right)$ in comparison to $592 \mathrm{mg} \mathrm{kg}^{-1}$ (354 $829 \mathrm{mg} \mathrm{kg}^{-1}$ ) during the low flow period.

The average concentration (range) of TP in surface water and bottom water was $0.058 \mathrm{mg} \mathrm{L}^{-1}\left(0.021 \sim 0.091 \mathrm{mg} \mathrm{L}^{-1}\right)$ and $0.054 \mathrm{mg} \mathrm{L}^{-1}\left(0.022 \sim 0.087 \mathrm{mg} \mathrm{L}^{-1}\right)$, respectively. The TP concentrations were found to exceed the threshold for eutrophication (Lai and Lam, 2008). The spatial distribution of TP in the overlying water was similar to that in the sediment, with only a little difference $(\mathrm{P}<0.01)$ (Fig. 2b, c). When the TP concentration in the sediment was high, similar high concentration was also measured in the corresponding water sample from this area, indicating the likely exchange and diffusion of $P$ between sediment and water in this area.

The variation characteristics of different forms of $P$ in sediment

Only knowing the TP concentration in sediment is not enough to predict the potential P supplying capacity (Jalali and Matin, 2013). Some inert $\mathrm{P}$ is deeply buried in sediment and therefore, would be slow to migrate to the overlying water. Thus, identifying and quantifying the different forms of $\mathrm{P}$ in sediment are important in order to characterize the sedimentary impact on biogeochemical cycling of $\mathrm{P}$ (Condron and Newman, 2011; Yates and Johnes, 2013).

The concentration of different forms of $\mathrm{P}$ varied among different sampling points as illustrated by box plots in Fig. 3, likely in response to intense human activities. The different forms of $\mathrm{P}$ also varied between high and low flow periods on the rivers. The average concentration of OP in sediment during the high flow period was $249 \mathrm{mg} \mathrm{kg}^{-1}$ (138 $408 \mathrm{mg} \mathrm{kg}^{-1}$ ) in comparison to $162 \mathrm{mg} \mathrm{kg}^{-1}$ (70 $265 \mathrm{mg} \mathrm{kg}^{-1}$ ) during the low flow period, accounting for $19 \sim 31 \%$ of TP. The average concentration of IP was $570 \mathrm{mg} \mathrm{kg}^{-1}$ during high flow period and $429.94 \mathrm{mg} \mathrm{kg}^{-1}$ during low flow period. The amount of IP accounted for 55-70\% of TP, suggesting that IP accounted for the majority of $\mathrm{P}$ in sediment. The average concentration of $\mathrm{HCl}-\mathrm{P}$ was $393 \mathrm{mg} \mathrm{kg}^{-1}$ during high flow period and $270 \mathrm{mg} \mathrm{kg}^{-1}$ during low flow period, accounting for $48 \sim 79 \%$ of IP. The concentration of $\mathrm{HCl}-\mathrm{P}$ was found to increase with increase in TP concentration and accounted for $38-56 \%$ of TP.

The average concentration (range) of NaOH-P was $177 \mathrm{mg} \mathrm{kg}^{-1}$ (115 $287 \mathrm{mg} \mathrm{kg}^{-1}$ ) during high flow period and $159 \mathrm{mg} \mathrm{kg}^{-1}$ (104 $208 \mathrm{mg} \mathrm{kg}^{-1}$ ) during low flow period, accounting for $25 \sim 45 \%$ of IP. For most of the sediment samples, the P fractions were found to be in the following order: $\mathrm{HCl}-\mathrm{P}>\mathrm{OP}>\mathrm{NaOH}-\mathrm{P}$. This distribution pattern was similar to those previously reported (Jin et al., 2013).

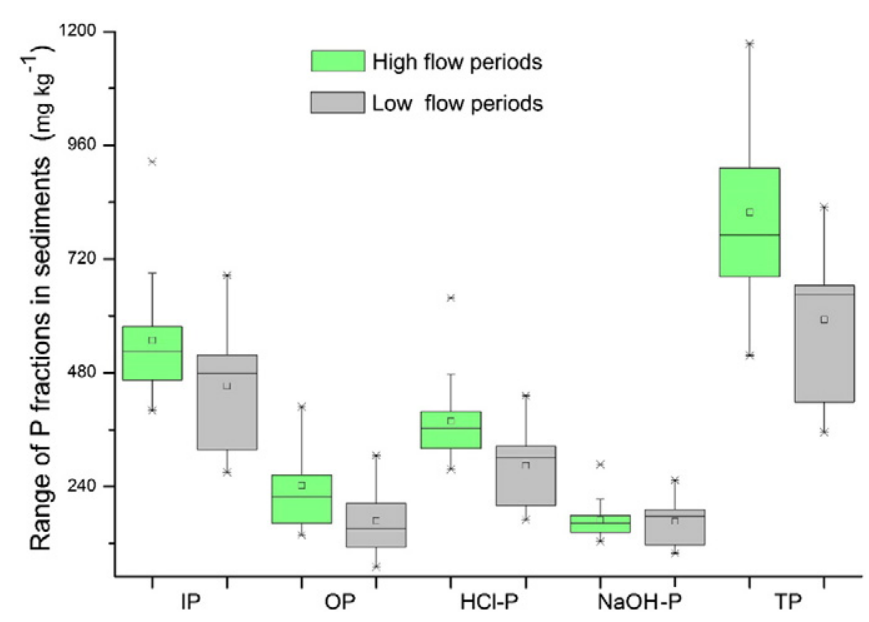

Fig. 3. Concentrations of five $P$ fractions in sediment during high flow period and low flow period of rivers. 


\section{Bioavailability of $P$ in sediment}

The concentration of bioavailable $P$ reflects the degree of pollution and the internal P release ability of sediment (Condron and Newman, 2011; Jin et al., 2013). Bioavailable P can be transformed into active $P$ through chemical or biological reactions, and in turn, will influence the overlying water quality (Powers et al., 2014; Chen et al., 2015). Several studies have shown that higher amounts of bioavailable P in sediment result in a greater release of P. Based on the previous research findings (Huang et al., 2013; Jin et al., 2013), approximately $50 \sim 60 \%$ of OP in sediment can be degraded or hydrolyzed into bioavailable P. In this study, bioavailable P was estimated as the sum of NaOH-P and $60 \%$ of OP. This gave an average value of $291 \mathrm{mg} \mathrm{kg}^{-1}$ in Dongting Lake sediment, accounting for ca. $41.4 \%$ of TP. Both the concentration and the proportion of bioavailable $\mathrm{P}$ were considerable, indicating that the potential availability and release risk to the overlying water were high.

\section{The vertical distributions of TP and forms of $P$ in sediment}

The vertical distribution of TP and different $P$ forms in lake sediment is the net result of historical sedimentation and are the result of various migration and transformation pathways during diagenesis. The vertical distribution of TP and different forms of P in lake sediment are shown in Fig. 4. The concentrations of IP and all the other fractions except OP behaved similarly to that of TP, whose concentrations showed a decreasing trend in the top $6 \sim 8 \mathrm{~cm}$. In contrast, the OP fractions in the cores increased with depth. The average concentrations of both TP and most of the different forms of $\mathrm{P}$ in surface sediment were significantly higher than those in deeper sediment in Western Dongting Lake, suggesting an enrichment of $\mathrm{P}$ at the surface (Fig. 4).

The vertical distributions of the average concentrations of TP and different forms of $\mathrm{P}$ were found to vary with location. The average concentrations of TP and various forms of P in cores C1, C5 and C6, which were collected in the estuary area, were higher than those in cores $\mathrm{C} 2, \mathrm{C} 3$, and $\mathrm{C4}$, which were collected in the center of the lake and in the main channel areas (far away from estuary). The vertical distributions of TP and various forms of $\mathrm{P}$ concentrations also had a smaller range in $\mathrm{C} 2, \mathrm{C} 3$, and $\mathrm{C} 4$ than in C1, C5 and C6, which can possibly be attributed to more complicated hydrodynamic exchange in estuary water. Hydrodynamics may result in large disturbances to the sediment and sediment transport and intensify $P$ exchange and diffusion at the sedimentwater interface (Crossman et al., 2013).

\section{The P adsorption characteristics in sediment}

To better characterize the P adsorption characteristics in tested sediments and the relation between the sediment adsorption capacity and the equilibrium concentration, the Langmuir equation was used to fit the experimental results and the relevant parameters were obtained
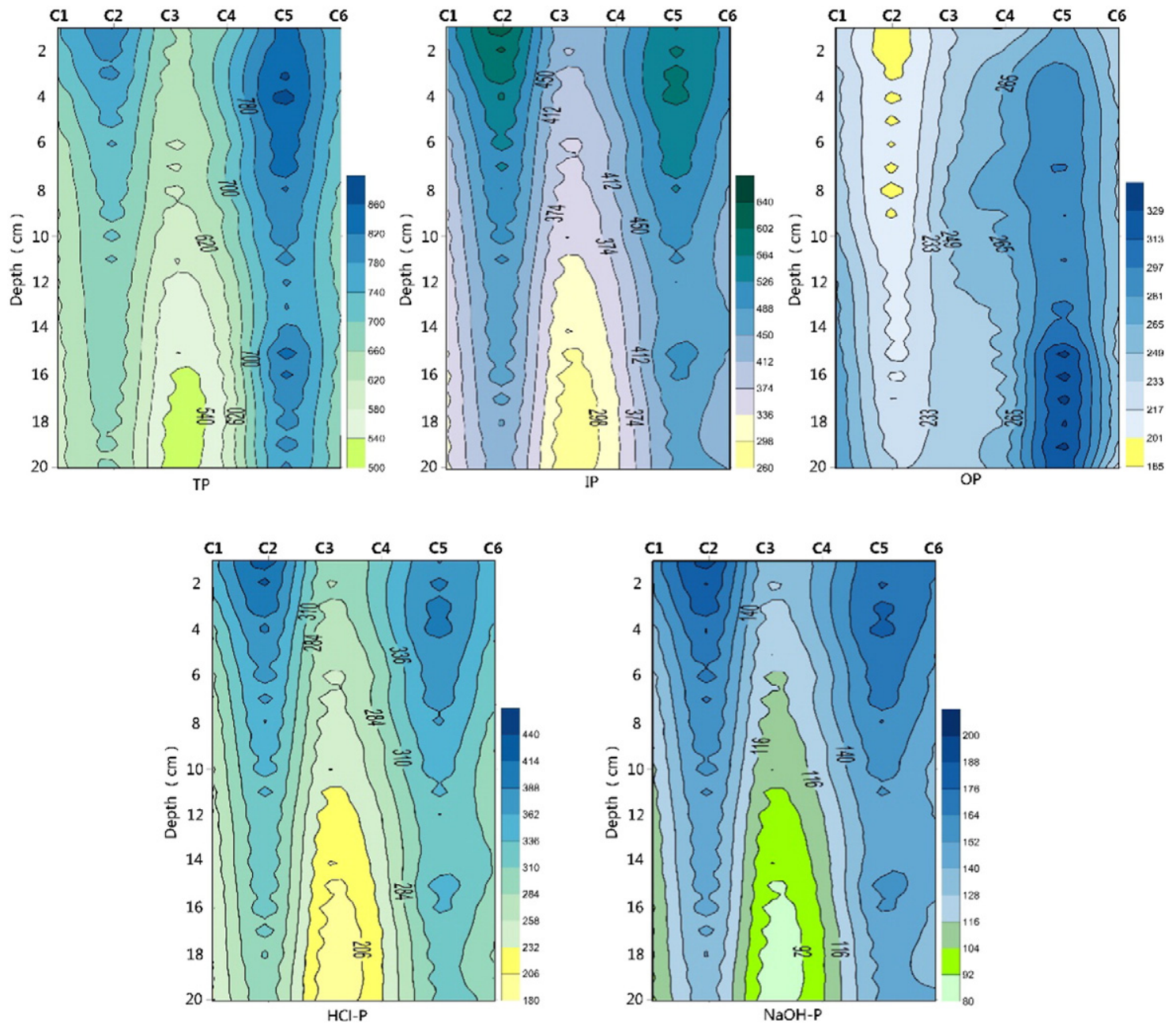

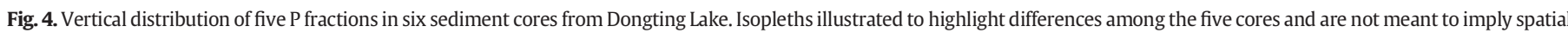
interpolation between the coring sites. 
Table 1

Isothermal adsorption parameters of $\mathrm{P}$ for the sediment samples and fit $\left(\mathrm{R}^{2}\right)$ of experimental data to the Langmuir equation.

\begin{tabular}{lllll}
\hline Sediment Core & $\mathrm{Qm}\left(\mathrm{mg} \mathrm{kg}^{-1}\right)$ & $\mathrm{K}\left(\mathrm{L} \mathrm{mg}^{-1}\right)$ & $\mathrm{MBC}\left(\mathrm{L} \mathrm{kg}^{-1}\right)$ & $\mathrm{R}^{2}$ \\
\hline C1 & 588.58 & 0.060 & 35.30 & 0.917 \\
C2 & 743.49 & 0.035 & 26.37 & 0.913 \\
C3 & 565.61 & 0.069 & 38.89 & 0.975 \\
C4 & 732.06 & 0.044 & 32.52 & 0.928 \\
C5 & 669.34 & 0.059 & 39.64 & 0.951 \\
C6 & 580.38 & 0.073 & 42.09 & 0.909 \\
\hline
\end{tabular}

(Table 1) (Fig. 5) (Crossman et al., 2013; Xie et al., 2013). The maximum adsorption of $\mathrm{P}$ in sediment $(\mathrm{Qm})$ can be obtained using the Langmuir equation to evaluate the enrichment degree and release risk of $\mathrm{P}$ in the sediment (Huang et al., 2013). These P adsorption values in the sediment in Dongting Lake ranged from 580 to $743 \mathrm{mg} \mathrm{kg}^{-1}$, which were higher than $32 \sim 132 \mathrm{mg} \mathrm{kg}^{-1}$ and $196 \sim 281 \mathrm{mg} \mathrm{kg}^{-1}$ reported in sediment from the Indian River Lagoon in Florida (Pant and Reddy, 2001) and from the largest marsh in Korea (Yoo et al., 2006), respectively. This may be attributed to the abundant specific surface area for P adsorption provided by the presence of amorphous $\mathrm{Fe}$ and $\mathrm{Al}$ in sediment (Jan et al., 2015). The adsorption equilibrium constants in Table 1 varied somewhat among different sediment cores, which were lower than $1.713 \sim 5.743 \mathrm{mg} \mathrm{L}^{-1}$ as reported in sediment from the Three-Gorges Reservoir (Wang et al., 2009).

Maximum buffer capacity (MBC), which is equal to the product of $\mathrm{Qm}$ and $\mathrm{K}$, reflects the sorption strength and capacity factor of $\mathrm{P}$ completely absorbed by sediment. A greater MBC in the sediment leads to a higher $\mathrm{P}$ concentration in the sediment solution. Compared with the MBC values of other shallow lakes in China ranged from 26.740 to $312.5 \mathrm{~L} \mathrm{~kg}^{-1}$ (Wang et al., 2007), the sediment samples of Dongting Lake had extremely low values that ranged from 26.37 to $42.09 \mathrm{~L} \mathrm{~kg}^{-1}$, suggesting that $\mathrm{P}$ of Dongting lakes was very mobile.

\section{The desorption characteristics of $P$ in sediment}

P desorption is generally recognized as the inverse process of adsorption (Jalali and Matin, 2013; Homyak et al., 2014). As shown in Fig. 6, the amount of P desorption of the six sediment cores tended to increase with increasing concentrations of adsorbed P. The desorption rate (the ratio of desorption quantity to adsorption quantity) ranged from $24.5 \%$ to $39.6 \%$. Also shown in Fig. 6, the isotherm desorption curve did not stabilize. Although the retention reached saturation,

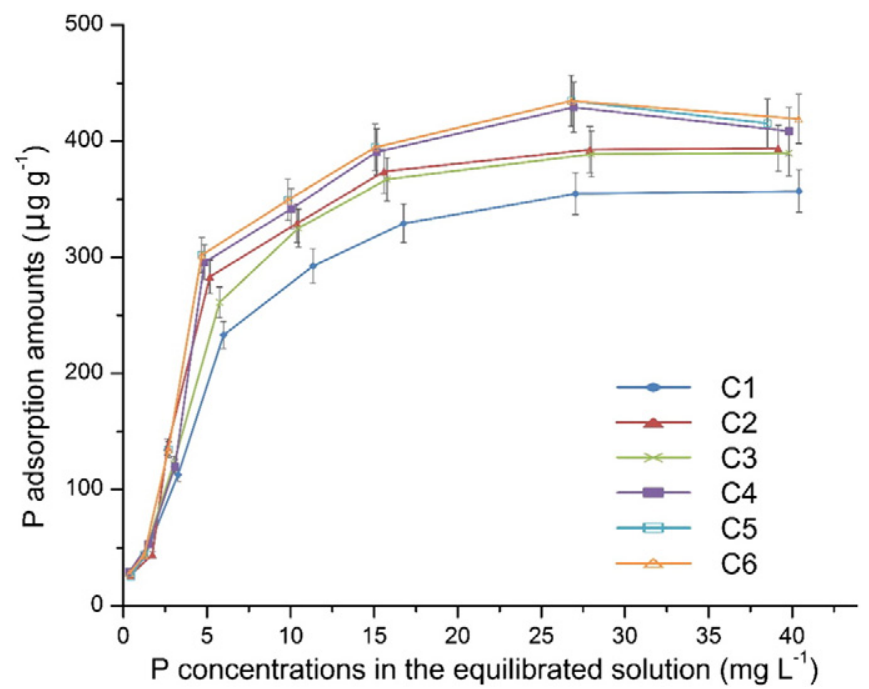

Fig. 5. Isothermal adsorption of P on sediments of Dongting Lake. The whisker lines on the adsorption curves are standard deviations.

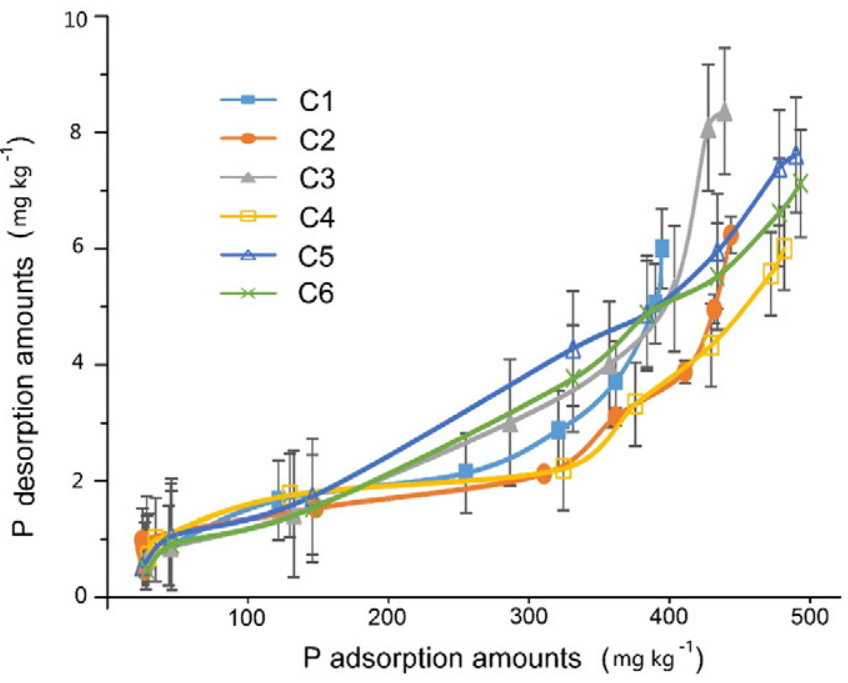

Fig. 6. Isothermal desorption of P from sediment of Dongting Lake. The whisker lines on the adsorption curves are standard deviations.

desorption still slightly increased as the P concentration increased. The result showed that the $\mathrm{P}$ adsorbed by chemisorption was not easily desorbed, but $\mathrm{P}$ absorbed by physical adsorption was easily desorbed. This phenomenon can be explained by the strength of each type of absorption (Lavoie and Auclair, 2012; Wang and Liang, 2014).

\section{Conclusions}

The results of the present study show that both the concentration and the proportion of bioavailable P in sediment of Dongting Lake were considerable, indicating that the potential availability and release risk to the overlying water were high. The fractions of P in sediment also varied with water flow. Therefore, the measures of contamination control and management with the comprehensive consideration of the entire basin, are required for aquatic system protection and future restoration of the Dongting Lake.

\section{Acknowledgments}

This study was sponsored by the National Key Project for Basic Research (No. 2012CB417004).

\section{References}

Chen, M., Ding, S., Liu, L., et al., 2015. Iron-coupled inactivation of phosphorus in sediments by macrozoobenthos (chironomid larvae) bioturbation: evidences from high-resolution dynamic measurements. Environ. Pollut. 204, 241-247.

Condron, L.M., Newman, S., 2011. Revisiting the fundamentals of phosphorus fractionation of sediments and soils. J. Soils Sediments 11 (5), 830-840.

Crossman, J., Whitehead, P.G., Futter, M.N., et al., 2013. The interactive responses of water quality and hydrology to changes in multiple stressors, and implications for the long-term effective management of phosphorus. Sci. Total Environ. 454, 230-244.

Ding, S.M., Han, C., Wang, Y.P., et al., 2015. In situ, high-resolution imaging of labile phosphorus in sediments of a large eutrophic lake. Water Res. 74 (0), 100-109.

Haggard, B.E., Scott, J.T., Patterson, S., 2012. Sediment phosphorus flux in an Oklahoma reservoir suggests reconsideration of watershed management planning. Lake Reservoir Manage. 28 (1), 59-69.

Homyak, P.M., Sickman, J.O., Melack, J.M., 2014. Phosphorus in sediments of highelevation lakes in the sierra Nevada (California): implications for internal phosphorus loading. Aquat. Sci. 76 (4), 511-525.

Huang, D., Wan, Q., Li, L., et al., 2013. Changes of water quality and eutrophic state in recent 20 years of Dongting Lake. Res. Environ. Sci. 26, 27-33.

Ishii, Y., Harigae, S., Tanimoto, S., et al., 2010. Spatial variation of phosphorus fractions in bottom sediments and the potential contributions to eutrophication in shallow lakes. Limnology 11 (1), 5-16.

Jalali, M., Matin, N.H., 2013. Soil phosphorus forms and their variations in selected paddy soils of Iran. Environ. Monit. Assess. 185 (10), 8557-8565.

Jan, J., Borovec, J., Kopáček, J., et al., 2015. Assessment of phosphorus associated with Fe and $\mathrm{Al}$ (hydr) oxides in sediments and soils. J. Soils Sediments 1-10. 
Jin, X., He, Y., Kirumba, G., et al., 2013. Phosphorus fractions and phosphate sorptionrelease characteristics of the sediment in the Yangtze River estuary reservoir. Ecol. Eng. 55, 62-66.

Kraal, P., Burton, E.D., Rose, A.L., et al., 2015. Sedimentary iron-phosphorus cycling under contrasting redox conditions in a eutrophic estuary. Chem. Geol. 392, 19-31.

Lai, D.Y.F., Lam, K.C., 2008. Phosphorus retention and release by sediments in the eutrophic Mai Po marshes, Hong Kong. Mar. Pollut. Bull. 57 (6), 349-356.

Lavoie, M., Auclair, J.C., 2012. Phosphorus mobilization at the sediment-water Interface in softwater Shield Lakes: the role of organic carbon and metal oxyhydroxides. Aquat. Geochem. 18 (4), 327-341.

Loh, P.S., Molot, L.A., Nurnberg, G.K., et al., 2013. Evaluating relationships between sediment chemistry and anoxic phosphorus and iron release across three different water bodies. Inland Waters 3 (1), 105-118.

Matias, N.G., Johnes, P.J., 2012. Catchment phosphorous losses: an export coefficient modelling approach with scenario analysis for water management. Water Resour. Manag. 26 (5), 1041-1064.

Nürnberg, G.K., Shaw, M., Dillon, P.J., et al., 1986. Internal phosphorus load in an oligotrophic Precambrian shield lake with an anoxic hypolimnion. Can. J. Fish. Aquat. Sci. 43 (3), 574-580.

Pant, H.K., Reddy, K.R., 2001. Phosphorus sorption characteristics of estuarine sediments under different redox conditions. J. Environ. Qual. 30 (4), 1474-1480.

Powers, S.M., Robertson, D.M., Stanley, E.H., 2014. Effects of lakes and reservoirs on annual river nitrogen, phosphorus, and sediment export in agricultural and forested landscapes. Hydrol. Process. 28 (24), 5919-5937.
Ruban, V., López-Sánchez, J.F., Pardo, P., et al., 1999. Selection and evaluation of sequential extraction procedures for the determination of phosphorus forms in lake sediment. J. Environ. Monit. 1 (1), 51-56.

Wang, L., Liang, T., 2014. Effects of exogenous rare earth elements on phosphorus adsorption and desorption in different types of soils. Chemosphere 103. 148-155.

Wang, S., Jin, X., Zhao, H., et al., 2007. Effect of organic matter on the sorption of dissolved organic and inorganic phosphorus in lake sediments. Colloids Surf. A Physicochem. Eng. Asp. 297 (1), 154-162.

Wang, Y., Shen, Z., Niu, J., et al., 2009. Adsorption of phosphorus on sediments from the three-gorges reservoir (China) and the relation with sediment compositions. J. Hazard. Mater. 162 (1), 92-98.

Xie, F., Wu, F., Liu, G., et al., 2013. Removal of phosphate from eutrophic lakes through adsorption by in situ formation of magnesium hydroxide from diatomite. Environ. Sci. Technol. 48 (1), 582-590.

Xu, G., Sun, J.N., Shao, H.B., et al., 2014. Biochar had effects on phosphorus sorption and desorption in three soils with differing acidity. Ecol. Eng. 62, 54-60.

Yates, C.A., Johnes, P.J., 2013. Nitrogen speciation and phosphorus fractionation dynamics in a lowland Chalk catchment. Sci. Total Environ. 444, 466-479.

Yoo, J.H., Ro, H.M., Choi, W.J., et al., 2006. Phosphorus adsorption and removal by sediments of a constructed marsh in Korea. Ecol. Eng. 27 (2), 109-117. 